\title{
Repurposing Drugs for Covid-19
}

\section{Amol Bhosale*}

Department of Pharmaceutical Sciences, India

*Corresponding Author: Amol Bhosale, Department of Pharmaceutical Sciences, India.

Coronavirus disease (COVID-19) is an infectious disease caused by severe acute respiratory syndrome coronavirus (SARS-CoV-2). COVID-19 is the next generation of the SARS-CoV virus. It have a zoonotic origin. coronavirus genetically clusters with genus Betacoronavirus, in subgenus Sarbecovirus. Common symptoms include fever, cough and shortness of breathing. In this condition, there are urgent for an effective treatment to treat COVID-19 infection. The decrease the order of community transmission is the global challenge. The discovery of new vaccine for covid-19 is the lengthy procedure. For current covid-19 world pandemic situation, repositioning of old drugs for the use of antiviral treatment is interesting method in this emergency condition.

The primary target is the stop the RNA replication and transcription of this virus. The replication cycle is stop using the finding routes of replication. There are the different inhibitors of COVID-19 replication. It also included kinases inhibitors, protease inhibitors and also endosomal $\mathrm{pH}$ regulators. The drugs are increase the $\mathrm{pH}$ in organelles like lysosomes, endosomes, Golgi vesicles of the virus. This is responsible for its antiviral activity. these drugs mainly inhibits the entry of virus into their host cell.

Chloroquine and Hydroxychloroquine is the anti-parasitic drug which was used against malaria disease. It has also used against zika virus and influenza A H5N1. Chloroquine is a weak base that becomes entrapped in membrane-enclosed low $\mathrm{pH}$ organelles, interfering with their acidification. In malaria-causing plasmodium parasites, Chloroquine accumulates in the digestion. If the Chloroquine and Hydroxychloroquine derivatives were applied against the COVID-19 virus, result may be shown like the lysosomal $\mathrm{pH}$ is increased and culture media restricted, proteases inhibition(proteolysis) is carried out. replication of virus required low $\mathrm{pH}$ and if $\mathrm{pH}$ is destroyed the release of the viral genome is prohibited. The Chloroquine may also affect on virion assembly of Golgi apparatus and endoplasmic reticulum.

Similarly, Antiviral medications like Lopinavir/ritonavir, Remdesivir were studied against COVID-19. This was active medications against viral replication or viral infection. It is an adenosine analogue, which is incorporates into nascent viral RNA chains and results in premature termination. Remdesivir was not FDA approved but it was used against the Ebola virus Ivermectin may a good effect like it has stop the growth of viral colonies. (this test was not performed on the human). The drugs like chlorpromazine can inhibit the entry of Covid-19 into the host cells.

Vitamin C (Ascorbic acid) consists of antioxidant properties. It doesn't have direct effect on Covid-19 but it regulates or maintain the endosomal $\mathrm{pH}$ regulation in the lysosomes.

Studies also found that antibiotics like azithromycin used against covid-19. azithromycin was also used for pneumonia diseases, which was happen because of bacterial infection. antiviral action of Azithromycin is not known. But some study find that it may have immunomodulatory properties. Which might be beneficial against pulmonary viral infections. It is also stable in acidic conditions [1-4].

\section{Bibliography}

1. Tony Y Hu., et al. "Insights from nanomedicine into chloroquine efficiency against COVID-19". Nature Nanotechnology 15.4 (2020): 247-249.

2. Rosa SGV and Santos WC. "Clinical trials on drug repositioning for COVID-19 treatment”. Revista Panamericana de Salud Pública 44 (2020): e40.

3. Bhumi Shah., et al. "In silico studies on therapeutic agents for COVID-19: Drug repurposing approach". Life Sciences 252 (2020).

4. Elsevier BV. "Fighting viruses with antibiotics: an overlooked path". International Journal of Antimicrobial Agents 48.4 (2016): 349-352.

\section{Assets from publication with us}

- Prompt Acknowledgement after receiving the article

- Thorough Double blinded peer review

- Rapid Publication

- Issue of Publication Certificate

- High visibility of your Published work

Website: www.actascientific.com/

Submit Article: www.actascientific.com/submission.php Email us: editor@actascientific.com Contact us: +919182824667 